\title{
PENERAPAN MODEL PEMBELAJARAN EXAMPLES NON EXAMPLES PADA MATERI KELOMPOK SOSIAL DALAM UPAYA PENINGKATAN PARTISIPASI DAN HASIL BELAJAR PESERTA DIDIK DI SMAN 2 BANJAR
}

\author{
Saeful Hadi \\ Sekolah Menengah Atas Negeri 2 Banjar, Indonesia \\ saeful.hadi.smanbanjar@gmail.com
}

\begin{abstract}
Abstrak: Penelitian ini bertujuan untuk mengetahui penerapan model pembelajaran Examples Non Examples ditinjau dari partisipasi dan hasil belajar peserta didik di SMAN 2 Banjar. Penelitian ini merupakan penelitian tindakan kelas dengan menggunakan 2 siklus. Pada setiap siklus terdiri dari perencanaan, pelaksanaan, observasi dan refleksi. Subjek pada penelitian ini adalah peserta didik kelas XI. IPS4 SMA Negeri 2 Banjar pada materi Kelompok Sosial pada mata pelajaran Sosiologi. Berdasarkan hasil penelitian menunjukkan peningkatan hasil yang dicapai peserta didik dalam menguasai materi kelompok sosial. Peningkatan partisipasi belajar hasil pengamatan dari pengamatan awal sampai siklus 2 mengalami peningkatan yaitu $57,69 \%$ (siklus 1) menjadi $81,73 \%$ (siklus 2), nilai rerata tes ada peningkatan dari siklus 1 yaitu dengan rata-rata nilai 70,45 ke siklus 2 yaitu dengan rerata nilai 78,29 serta jumlah peserta didik yang tuntas dan persentase ketuntasan belajar pun meningkat dari 17 orang atau $54,84 \%$ menjadi 24 orang atau $77,42 \%$ pada siklus 2 .
\end{abstract}

Kata kunci: Sosiologi, Examples Non Examples, Kelompok Sosial, Hasil Belajar, Partisipasi

\section{APPLICATION OF EXAMPLES NON EXAMPLES LEARNING MODELS ON SOCIAL GROUP MATERIALS IN INCREASING PARTICIPATION EFFORTS AND STUDENT LEARNING OUTCOMES IN SMAN 2 BANJAR}

\begin{abstract}
This study aims to determine the application of learning models Examples Non Examples in terms of participation and learning outcomes of students at SMAN 2 Banjar. This research is a classroom action research using 2 cycles. In each cycle consists of planning, implementation, observation and reflection. The subjects in this study were students of class XI. IPS4 SMA 2 Banjar on Social Group material on Sociology subjects. Based on the results of the study showed an increase in the results achieved by students in mastering social group material. Increased learning participation observations from the initial observation until the second cycle experienced an increase of $57.69 \%$ (cycle 1) to $81.73 \%$ (cycle 2), the average score of the test was an increase from cycle 1 which is an average of 70.45 to cycle 2 is the average value of 78.29 and the number of students who complete and the percentage of mastery learning increases from 17 people or $54.84 \%$ to 24 people or $77.42 \%$ in cycle 2 .
\end{abstract}

Keywords: Sociology, Examples Non Examples, Social Groups, Learning Outcomes, Participation

\section{PENDAHULUAN}

Profesi guru pada dinamika perkembangannya dituntut untuk semakin meningkatkan kualitas dalam proses pembelajaran yang menjadi tanggung jawabnya. Oleh karena itu guru dituntut untuk memiliki kreativitas dan inovasi dalam menjalankan profesinya. Diharapkan proses pembelajaran peserta didik dikondisikan nyaman dan menyenangkan serta memperoleh hasil belajar yang lebih optimal. Kreativitas adalah salah satu kata kunci yang perlu dilakukan guru untuk memberikan layanan pendidikan yang maksimal sesuai dengan kemampuan dan keahlian khusus dalam bidang keguruan. Begitu pula pada proses pembelajaran di kelas, guru harus memiliki kreativitas dan 
inovasi sehingga pembelajaran berlangsung menarik dan peserta didik nyaman dalam belajar serta antusias. Salah satu ciri kreatif yaitu kemampuan menggabungkan sesuatu yang belum pernah tergabung sebelumnya dengan ide-ide baru yang berguna dalam pemecahan masalah berkaitan dengan proses pembelajaran di kelas.

Tuntutan mengembangkan kreativitas guru di kelas adalah keniscayaan agar suasana proses belajar mengajar semakin menyenangkan, sehingga hasil belajar peserta didik semakin meningkat. Tugas dan peran guru seperti yang diamanatkan dalam Undang-Undang No. 14 Tahun 2005 Tentang Guru dan Dosen yaitu guru dituntut untuk selalu meningkatkan kemampuan berbagai kecerdasan sehingga mampu pula menghasilkan sumber daya manusia yang berkualitas. Pengembangan kemampuan guru dalam penerapan model pembelajaran yang bervariasi semakin menjadi tuntutan sehingga menghasilkan suasana belajar yang menyenangkan dan bermakna bagi peserta didik serta memperoleh hasil pembelajaran yang maksimal pula. Proses pembelajaran model klasik yang berpandangan bahwa peserta didik adalah tabung kosong yang hanya diisi oleh guru harus mulai ditinggalkan karena pada hakikatnya peserta didik memiliki berbagai potensi kecerdasan yang dapat dikembangkan. Pada tataran modern seperti sekarang ini, guru lebih kepada fasilitator bagi peserta didik dalam rangka mengembangkan potensi kecerdasan yang dimilikinya. Guru tidak lagi dominan dan seolah-olah yang paling segala tahu. Guru harus melakukan perubahan dengan lebih berperan membimbing peserta didik dalam proses pembelajarannya agar bisa mandiri dan lebih bermakna.

Pembelajaran adalah suatu sistem yang bertujuan untuk membantu proses belajar siswa, yang berisi serangkaian peristiwa yang dirancang, disusun sedemikian rupa untuk memengaruhi dan mendukung terjadinya proses belajar peserta didik yang bersifat internal (Nurochim, 2013). Pembelajaran adalah suatu kombinasi yang tersusun meliputi unsur-unsur manusiawi, material, fasilitas, perlengkapan, dan prosedur yang saling mempengaruhi mencapai tujuan pembelajaran (Hamalik, 2005).

Model pembelajaran adalah kerangka konseptual yang melukiskan prosedur yang sistematis dalam mengorganisasikan pengalaman belajar untuk mencapai tujuan pembelajaran tertentu, memiliki fungsi sebagai pedoman bagi para perancang pembelajaran dan para pengajar dalam merencanakan serta melaksanakan aktivitas belajar mengajar. Pembelajaran Examples Non Examples termasuk dalam pembelajaran kontekstual (Contextual Teaching and Learning) (Aqib, 2014). Pembelajaran kontekstual merupakan konsep belajar dan mengajar yang membantu guru mengaitkan antara materi yang diajarkannya dengan situasi dunia nyata siswa dan mendorong siswa membuat hubungan antara pengetahuan yang dimilikinya dengan penerapannya dalam kehidupan mereka sebagai anggota keluarga, warga negara, dan pekerja. Contextual Teaching And Learning (CTL) atau pembelajaran kontekstual adalah pendekatan pembelajaran yang mengaitkan antara materi yang dipelajari dengan kehidupan nyata siswa sehari-hari, baik dalam lingkungan keluarga, sekolah, masyarakat maupun warga negara, dengan tujuan untuk menemukan makna materi tersebut bagi kehidupannya. Salah satu varian model pembelajaran kontekstual ini adalah model Examples Non Examples (Komalasari, 2011).

Model Examples Non Examples adalah model pembelajaran yang didasarkan atas contoh. Contoh dapat diambil dari kasus atau gambar yang relevan dengan kompetensi dasar. Examples Non Examples adalah model pembelajaran yang membelajarkan peserta didik terhadap permasalahan yang ada di sekitarnya melalui analisis contoh-contoh berupa gambar-gambar, foto dan kasus yang bermuatan masalah (Komalasari, 2011). Peserta didik diarahkan untuk mengidentifikasi masalah, mencari alternatif pemecahan masalah, dan menentukan cara pemecahan masalah yang paling efektif, serta melakukan tindak lanjut. Model Examples Non Examples ini termasuk dalam salah satu 
metode pembelajaran dengan menggunakan media kertas dan pensil (Sani, 2015). Hal tersebut untuk mengarahkan siswa dapat menentukan manakah contoh yang benar dan manakah contoh yang salah melalui media kertas yang berupa gambar tersebut.

Konsep model pembelajaran ini pada umumnya dipelajari melalui dua cara (Shoimin, 2014). Paling banyak konsep yang kita pelajari di luar sekolah melalui pengamatan dan juga melalui definisi konsep itu sendiri. Examples Non Examples adalah taktik yang dapat digunakan untuk mengajarkan definisi konsep. Taktik ini bertujuan untuk mempersiapkan siswa secara cepat menggunakan dua hal yang terdiri dari Examples dan Non Examples dari suatu definisi konsep yang ada, dan meminta siswa untuk mengklasifikasikan keduanya sesuai dengan konsep yang ada.

Examples memberikan gambaran akan sesuatu yang menjadi contoh terhadap suatu materi yang sedang dibahas, sedangkan Non Examples memberikan gambaran akan sesuatu yang bukanlah contoh dari suatu materi yang sedang dibahas. Dengan memusatkan perhatian siswa terhadap Examples dan Non Examples, diharapkan akan dapat mendorong siswa untuk menuju pemahaman yang lebih dalam mengenai materi yang ada.

Pembelajaran model Examples Non Examples ini juga termasuk dalam pembelajaran tipe kooperatif karena memberi ruang dan kesempatan yang luas kepada setiap anggota kelompok untuk bertatap muka saling memberikan informasi dan saling membelajarkan. Interaksi tatap muka akan memberikan pengalaman yang berharga kepada setiap anggota kelompok untuk bekerja sama, menghargai setiap perbedaan, memanfaatkan kelebihan masing-masing anggota, dan mengisi kekurangan masing-masing (Shoimin, 2014).

Pembelajaran pada mata pelajaran sosiologi dituntut kreatif agar pembelajaran semakin menyenangkan dan menimbulkan partisipasi yang maksimal dari peserta didik. Oleh karena itu perlu adanya suatu penelitian tindakan yang berupaya mendiagnosis bagaimana permasalahan partisipasi peserta didik dalam proses pembelajaran di kelas. Persoalan bahwa pelajaran sosiologi memang menuntut pemikiran tingkat tinggi bahkan sampai ke penalaran, diperlukan model pembelajaran yang lebih bervariasi agar partisipasi peserta didik dalam proses pembelajaran lebih meningkat serta hasil belajarnya yang maksimal dan mencapai ketuntasan yang diinginkan.

Hasil belajar adalah kemampuan-kemampuan yang dimiliki peserta didik setelah menerima pengalaman belajarnya (Sudjana, 2008). Hasil belajar adalah pola-pola perbuatan, nilai-nilai, pengertian-pengertian dan sikap-sikap serta kemampuan peserta didik (Hamalik, 2003). Hasil belajar sebagai kompetensi atau kemampuan tertentu baik kognitif, afektif maupun psikomotorik yang dicapai atau dikuasai peserta didik setelah mengikuti proses belajar mengajar (Kunandar, 2013). Berdasarkan pengertian tersebut dapat disimpulkan bahwa hasil belajar adalah kemampuan yang dimiliki peserta didik setelah peserta didik mendapatkan pengalaman belajarnya yang mencakup aspek kognitif, psikomotor dan afektif untuk dijadikan bahan penilaian dan evaluasi.

Partisipasi belajar merupakan salah satu hasil dari motivasi belajar baik yang bersifat intrinsik atau bersumber dari dalam diri peserta didik sendiri maupun motivasi ekstrinsik yang bersumber dari luar peserta didik (Hamalik, 2005). Agar motivasi yang berujung pada partisipasi maksimal peserta didik dalam proses pembelajaran, diperlukan suatu kondisi-kondisi yang relevan dan salah satunya adalah perpaduan model pembelajaran dan media yang tepat. Dalam diri masing-masing peserta didik terdapat prinsip aktif yakni keinginan berbuat dan bekerja sendiri. Oleh karena itu, didukung berbagai kegiatan yang diimplementasikan dalam kegiatan pembelajaran dan salah satunya yaitu kegiatan-kegiatan visual, maka dibutuhkan kreativitas guru dalam membangun atau meningkatkan partisipasi belajar peserta didik.

Proses pembelajaran pada mata pelajaran sosiologi sangat menuntut bukan hanya berkaitan dengan konsep-konsep atau teori-teori yang harus dihafal, tetapi juga membutuhkan proses berpikir 
yang menggunakan logika analisis sehingga terjadi hubungan yang signifikan dan relevan dengan dunia sehari-hari. Peserta didik diharapkan tidak sekedar memahami teori dan konsep, namun juga memahami realitas sosial yang terjadi yang relevan dan signifikan. Oleh karena itu, model pembelajaran yang bersifat kontekstual dan gambaran nyata dalam kehidupan sehari-hari, penulis coba terapkan dalam penelitian tindakan kelas ini melalui media gambar-gambar yang berkaitan dengan tema materi pembelajaran.

Materi pembelajaran sosiologi memang sangatlah berkaitan erat dengan fenomena aktual yang terjadi dalam kehidupan sehari-hari khususnya yang diliput oleh media massa baik cetak maupun elektronik. Namun tidak semua peserta didik mampu menjangkau sumber pembelajaran yang relevan dengan tema, oleh karena itu penulis mencoba memfasilitasi hal tersebut dengan menerapkan model pembelajaran yang berbasis media gambar dan informasi dari berbagai sumber khususnya internet.

Model pembelajaran Examples Non Examples bisa lebih efektif jika disertai dengan media pembelajaran yang tepat. Media pembelajaran adalah salah satu aspek penting dalam kegiatan proses pembelajaran di kelas. Bagaimana pun setiap pesan yang tersampaikan atau materi yang tersosialisasikan diperlukan suatu media dalam implementasi prosesnya. Pesan yang dikirimkan biasanya berupa informasi atau keterangan dari pengirim (sumber) pesan (Susilana, 2009). Pesan tersebut diubah dalam bentuk sandi-sandi atau lambang-lambang seperti kata-kata, bunyi-bunyi, gambar dan sebagainya. Melalui saluran (channel) seperti radio, televisi, OHP, film, video, pesan yang diterima oleh penerima pesan melalui indera (mata dan telinga) untuk diolah, sehingga pesan yang disampaikan oleh penyampai pesan dapat diterima dan dipahami oleh penerima pesan. Proses tersebut memerlukan suatu alat atau sarana yang disebut dengan media.

Pada penerapan model pembelajaran Examples Non Examples pada eksperimen penelitian ini menggunakan media hasil teknologi cetak yaitu gambar. Gambar atau foto merupakan media pembelajaran yang sering digunakan karena termasuk media sederhana dan tidak memerlukan biaya yang mahal (Kustandi \& Sutjipto, 2016). Media ini merupakan bahasa yang umum, dapat dimengerti, dan dinikmati oleh semua orang di mana-mana. Gambar berfungsi untuk menyampaikan pesan melalui gambar yang menyangkut indera penglihatan. Pesan yang disampaikan dituangkan ke dalam simbol-simbol komunikasi visual. Simbol-simbol tersebut perlu dipahami dengan benar agar proses penyampaian pesan dapat berhasil dan efisien.

Oleh karena itu penerapan model pembelajaran Examples Non Examples dengan tujuan agar aktivitas belajar serta perhatian peserta didik lebih fokus diharapkan dapat meningkatkan hasil belajar dan meningkatnya rerata hasil belajar peserta didik untuk dapat memenuhi target standar minimal atau KKM. Oleh karena itu, penelitian ini menganalisis mengenai penerapan model pembelajaran examples non examples pada mata pelajaran sosiologi materi kelompok sosial dalam upaya peningkatan partisipasi dan hasil belajar peserta didik kelas XI.IPS4 SMAN 2 Banjar.

\section{METODE}

Penelitian ini merupakan penelitian tindakan kelas (PTK). Penelitian ini dilaksanakan melalui dua siklus, dengan opsi tambahan satu siklus lagi jika hasil dua siklus belum memenuhi harapan, untuk melihat peningkatan partisipasi belajar dan hasil belajar peserta didik dalam mengikuti mata pelajaran Sosiologi melalui penerapan model pembelajaran Examples non examples. Penelitian ini dilaksanakan di Kelas XI.IPS4 SMAN 2 Banjar. Penelitian ini dilaksanakan pada genap tahun ajaran 2016/2017, yaitu bulan Januari sampai dengan Maret 2017. Penentuan waktu penelitian mengacu pada kalender akademik sekolah, karena PTK memerlukan beberapa siklus yang membutuhkan proses belajar mengajar yang efektif di kelas. Subjek penelitian adalah peserta didik 
kelas XI.IPS4 yang terdiri dari 31 orang peserta didik dengan komposisi peserta didik perempuan 20 orang dan peserta didik laki-laki 11 orang. Sumber data dalam penelitian ini terdiri dari beberapa sumber, yakni peserta didik, guru serta teman sejawat dan kolaborator. Teknik pengumpulan data dalam penelitian ini adalah tes, observasi, dan diskusi.

Data yang dihimpun pada setiap kegiatan observasi dari tahapan pelaksanaan siklus penelitian dianalisis secara deskriptif untuk melihat kecenderungan yang terjadi pada proses pembelajaran dengan menggunakan teknik persentase. Hasil persentase ini adalah untuk menentukan berbagai generalisasi atau kesimpulan dari tujuan dilaksanakan penelitian tindakan kelas ini. Bagian ini memuat rancangan atau desain penelitian yang dilakukan. Pada bagian ini paling tidak memuat tentang jenis penelitian, subjek/objek penelitian, teknik/instrumen pengumpulan data dan analisis data. Masing-masing bagian dikemas secara naratif dan tidak perlu membuat subbab tersendiri.

1. Aktivitas peserta didik dalam proses pembelajaran sosiologi dengan menganalisis tingkat partisipasi dan keaktifan peserta didik dalam proses belajar mengajar sosiologi. Kemudian dikategorikan dalam klasifikasi tinggi, sedang, dan rendah.

2. Hasil belajar: dengan menganalisis nilai rata-rata ulangan harian. Baik perbandingan dengan nilai rata-rata ulangan harian sebelumnya maupun dengan mengkategorikan dalam klasifikasi tinggi, sedang, dan rendah.

3. Ketuntasan belajar setiap individu: setiap peserta didik dinyatakan tuntas terhadap materi pembelajaran yang diberikan jika mencapai nilai lebih besar atau sama dengan nilai Kriteria Ketuntasan Minimal (KKM) yaitu 76.

PTK ini merujuk pada model Kurt Lewin (Kunandar, 2012) yang menggambarkan tahapan siklus pengamatan dan evaluasi pada empat komponen pokok yaitu: perencanaan (planning), pelaksanaan/tindakan (acting), pengamatan (observing), dan refleksi (reflecting). Adapun modelnya menurut Arikunto (2014) dapat digambarkan seperti berikut ini:

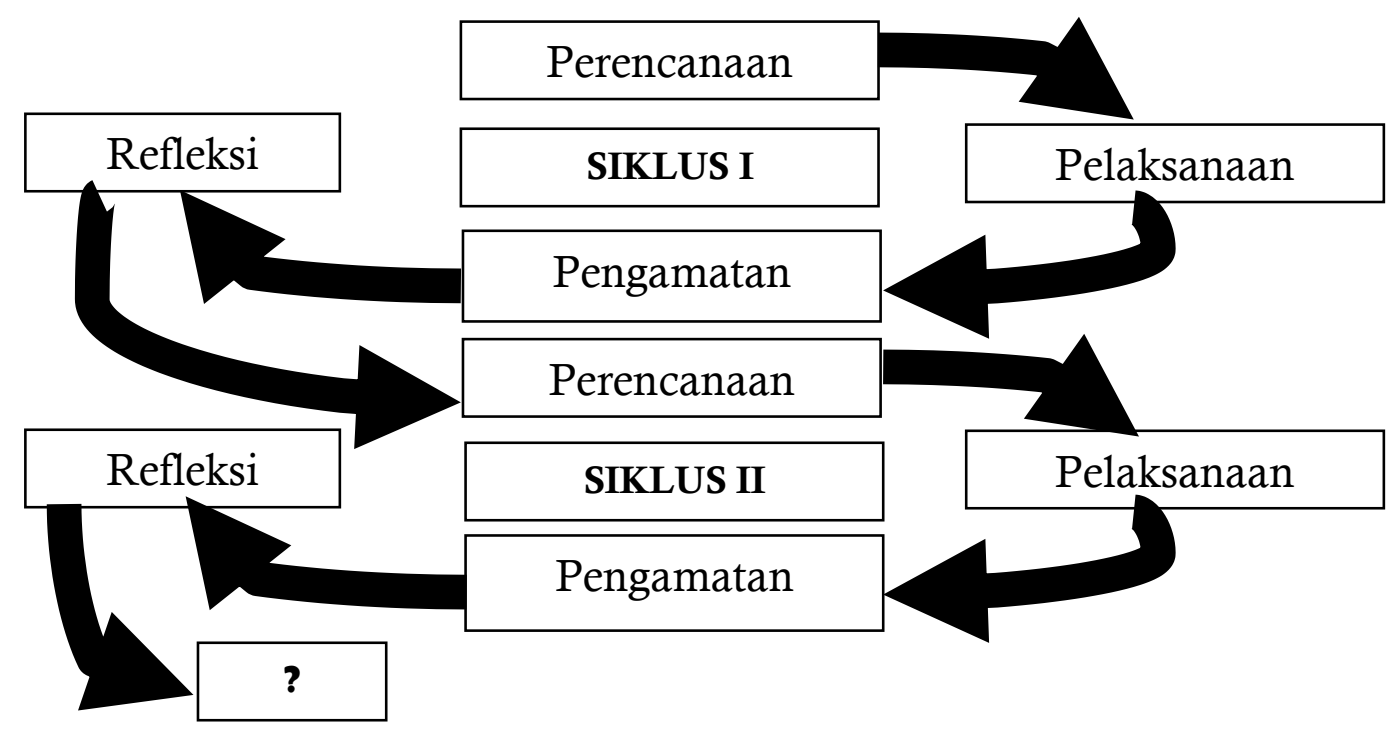

Gambar 1. Model Alur Penelitian Tindakan Kelas

Penelitian ini dilaksanakan dalam dua siklus, dengan opsi menambah satu siklus lagi jika hasilnya masih tidak sesuai harapan. Siklus pertama dan kedua dalam penelitian ini terdiri dari perencanaan, pelaksanaan, pengamatan dan refleksi. 


\section{HASIL DAN PEMBAHASAN \\ Hasil}

Penelitian diawali dengan observasi dan pengumpulan data dari kondisi awal kelas yang akan diberi tindakan, yaitu kelas XI IPS 4 SMAN 2 Banjar. Pengetahuan awal ini perlu diketahui agar kiranya penelitian ini memberikan gambaran pasti mengenai kronologis proses yang terjadi dan sesuai dengan apa yang diharapkan oleh peneliti, apakah benar kiranya kelas ini perlu diberi tindakan yang sesuai dengan apa yang akan diteliti oleh peneliti yaitu Penerapan Model Pembelajaran Examples non examples pada Materi Kelompok Sosial Dalam Upaya Peningkatan Partisipasi dan Hasil belajar peserta didik. Asumsi yang dibangun juga dilatarbelakangi oleh pengalaman pembelajaran pada semester sebelumnya yang kondisinya cenderung kurang memuaskan terutama berkaitan dengan aktivitas dan partisipasi peserta didik yang kurang maksimal.

\section{Siklus 1}

1. Perencanaan (planning):

a. Peneliti membuat program atau skenario kegiatan pembelajaran termasuk mempersiapkan silabus dan RPP yang sesuai dengan tujuan kegiatan PTK yang akan dilaksanakan khususnya berkaitan dengan penerapan media visual gambar pada model pembelajaran Examples non examples;

b. Menyusun rencana pelaksanaan pembelajaran yang strateginya dengan penerapan media gambar pada model pembelajaran Examples non examples untuk materi Kelompok Sosial;

c. Membuat dan menyusun media pembelajaran yaitu dengan menggunakan media gambargambar hasil print out kertas dengan tema yang relevan dari internet;

d. Membuat lembar kerja siswa;

e. Memantapkan jumlah dan anggota kelompok belajar;

f. Membuat berbagai instrumen yang digunakan dalam siklus PTK;

g. Menyusun alat evaluasi pembelajaran.

2. Pelaksanaan (acting):

a. Pelaksanaan kegiatan adalah hari Rabu

b. Mengarahkan peserta didik kelompok belajar kecil dengan teman sebangku;

c. Membagi Lembar Kerja Peserta didik dan petunjuknya serta menempelkan beberapa gambar di papan tulis;

d. Menyajikan materi pembelajaran dengan ceramah singkat dan skenario proses pembelajaran yang akan dilaksanakan yaitu berkaitan dengan materi kelompok sosial;

e. Guru mengarahkan peserta didik dalam proses diskusi dan mempersilahkan untuk menanggapi gambar-gambar yang ditampilkan;

f. Guru memberikan penguatan dan kesimpulan secara bersama-sama dengan siswa;

g. Guru melakukan evaluasi atau tes di akhir pembelajaran.

3. Pengamatan (observation):

a. Kolabolator/pengamat mengamati pengelolaan pembelajaran penerapan media gambar pada model pembelajaran Examples non examples;

b. Kolabolator diberi kesempatan mencatat kelemahan dan kekuatan guru dalam melaksanakan tindakan di kelas serta aktivitas peserta didik dalam mengikuti pembelajaran beserta kendalanya;

c. Pada tahap ini dilakukan penilaian dan evaluasi terhadap kegiatan yang dilakukan dengan instrumen yang disediakan;

d. Pada tahapan ini pula diketahui bagaimana hasil belajar peserta didik dengan skenario pembelajaran yang direncanakan. 
4. Hasil Kegiatan dan Pengamatan

Tabel 1. Hasil Pengamatan Aktivitas Pembelajaran Pada Siklus 1

\begin{tabular}{|c|c|c|c|c|}
\hline \multirow{2}{*}{ No. } & \multirow{2}{*}{ Aspek yang diamati } & \multicolumn{2}{|c|}{ Penilaian } & \multirow{2}{*}{$\begin{array}{l}\text { Rata- } \\
\text { rata }\end{array}$} \\
\hline & & $\mathrm{P} 1$ & $\mathrm{P} 2$ & \\
\hline \multirow[t]{14}{*}{$\mathrm{I}$} & Pengamatan PBM & & & \\
\hline & A. Pendahuluan & & & \\
\hline & 1. Memotivasi peserta didik & 2 & 2 & 2 \\
\hline & 2. Menyampaikan Tujuan pembelajaran & 3 & 3 & 3 \\
\hline & B. Kegiatan Inti & & & \\
\hline & $\begin{array}{l}\text { 1. Mendiskusikan langkah-langkah kegiatan bersama } \\
\text { peserta didik }\end{array}$ & 2 & 2 & 2 \\
\hline & 2. Membimbing peserta didik melakukan kegiatan & 3 & 3 & 3 \\
\hline & 3. Mendiskusikan dengan peserta didik hasil kegiatan & 2 & 2 & 2 \\
\hline & 4. Memberikan kesempatan peserta didik untuk & & & \\
\hline & $\begin{array}{l}\text { menyampaikan hasil pengamatan dan pencarian } \\
\text { informasi pada proses pembelajaran }\end{array}$ & 3 & 3 & 3 \\
\hline & 5. Membimbing peserta didik menyampaikan kesimpulan & 2 & 2 & 2 \\
\hline & C. Penutup & & & \\
\hline & 1. Membimbing peserta didik melakukan rangkuman & 2 & 2 & 2 \\
\hline & 2. Memberikan evaluasi & 3 & 3 & 3 \\
\hline II & Pengelolaan Waktu & 2 & 2 & 2 \\
\hline \multirow[t]{7}{*}{ III } & Partisipasi Siswa & & & \\
\hline & 1. Antusiasme memberikan tanggapan & 2 & 2 & 2 \\
\hline & 2. Mengajukan pertanyaan & 2 & 2 & 2 \\
\hline & 3. Menyampaikan pendapat/argumentasi & 2 & 2 & 2 \\
\hline & Jumlah & 30 & 30 & 30 \\
\hline & Rata-rata & 2,31 & 2,31 & 2,31 \\
\hline & Persentase & 57,69 & 57,69 & 57,69 \\
\hline
\end{tabular}

Keterangan

Kriteria Nilai: (1) Tidak baik, (2) Kurang baik, (3) Cukup baik, (4) Baik

5. Refleksi (reflecting):

Berdasarkan data pada siklus 1 ada beberapa hal yang bisa diungkapkan untuk dianalisis yaitu guru dalam proses pembelajaran masih kurang dalam menyampaikan motivasi kepada siswa, langkah-langkah kegiatan pembelajaran belum sepenuhnya dipahami peserta didik dan masih minoritas keterlibatan atau partisipasi peserta didik untuk menyampaikan hasil pengamatan dan pencarian informasi, serta penyampaian kesimpulan belum maksimal.

Tabel 2. Rekapitulasi Hasil Tes Peserta didik Pada Siklus 1

\begin{tabular}{llc}
\hline No. & Uraian & Hasil Siklus 1 \\
\hline 1. & Nilai rata-rata perolehan siswa & 70,45 \\
2. & Jumlah peserta didik yang tuntas belajar & 17 \\
3. & Persentase ketuntasan belajar & $54,84 \%$ \\
\hline
\end{tabular}

Kemudian dari aspek kondisi aktivitas belajar peserta didik menggambarkan antusiasme belum cukup tinggi serta peserta didik kurang aktif dalam mengajukan pertanyaan dan menyampaikan pendapat. Sementara itu, data hasil tes atau evaluasi juga memperlihatkan hasil yang belum memuaskan yaitu dari 31 orang jumlah siswa, ternyata hanya 17 orang yang tuntas atau hanya 54,84\% dengan nilai rata-rata 70,45. Angka tersebut masih belum mencapai target yaitu $75 \%$. Oleh karena itu, maka peneliti berdasarkan data yang diperoleh pada siklus 1 dan masukan dari rekan sejawat sebagai observer melakukan perencanaan untuk siklus 2 dengan melakukan perbaikan-perbaikan sesuai indikator yang belum memadai pada siklus 1 . 


\section{Siklus 2}

1. Perencanaan (planning):

a. Mengidentifikasi masalah dan merumuskannya berdasarkan refleksi siklus 1 .

b. Peneliti membuat rancangan pembelajaran berdasarkan hasil refleksi siklus pertama dengan berbagai perbaikan khususnya dalam meningkatkan kemampuan peserta didik dalam bertanya dan menyampaikan pendapat.

c. Tampilan berbagai gambar lebih fokus, menarik dan relevan dengan materi kelompok sosial.

d. Pembagian kelompok peserta didik lebih heterogen agar peserta didik yang kurang antusias mendapatkan bimbingan dari teman diskusi yang memadai untuk mampu menyampaikan pendapat serta mendapatkan pemahaman materi pelajaran melalui diskusi kelompok.

Tabel 3. Hasil Pengamatan Aktivitas Pembelajaran Pada Siklus 2

\begin{tabular}{|c|c|c|c|c|}
\hline \multirow[b]{2}{*}{ No. } & \multirow{2}{*}{ Aspek yang diamati } & \multicolumn{2}{|c|}{ Penilaian } & \multirow[t]{2}{*}{ Rerata } \\
\hline & & P1 & P2 & \\
\hline \multirow[t]{13}{*}{ I } & \multirow{2}{*}{\multicolumn{4}{|c|}{$\begin{array}{l}\text { Pengamatan PBM } \\
\text { A. Pendahuluan }\end{array}$}} \\
\hline & & & & \\
\hline & 1. Memotivasi peserta didik & 3 & 4 & 3,5 \\
\hline & 2. Menyampaikan Tujuan pembelajaran & 3 & 4 & 3,5 \\
\hline & \multicolumn{4}{|l|}{ B. Kegiatan Inti } \\
\hline & 1. Mendiskusikan langkah-langkah kegiatan bersama siswa & 3 & 3 & 3 \\
\hline & 2. Membimbing peserta didik melakukan kegiatan & 3 & 3 & 3 \\
\hline & 3. Mendiskusikan dengan peserta didik hasil kegiatan & 3 & 4 & 3,5 \\
\hline & $\begin{array}{l}\text { 4. Memberikan kesempatan peserta didik untuk } \\
\text { menyampaikan hasil pengamatan dan pencarian } \\
\text { informasi pada proses pembelajaran }\end{array}$ & 3 & 3 & 3 \\
\hline & 5. Membimbing peserta didik menyampaikan kesimpulan & 3 & 3 & 3 \\
\hline & \multicolumn{4}{|l|}{ C. Penutup } \\
\hline & 1. Membimbing peserta didik melakukan rangkuman & 3 & 3 & 3 \\
\hline & 2. Memberikan evaluasi & 3 & 4 & 3,5 \\
\hline II & Pengelolaan Waktu & 3 & 3 & 3 \\
\hline \multirow[t]{7}{*}{ III } & Partisipasi Siswa & & & \\
\hline & 4. Antusiasme memberikan tanggapan & 3 & 3 & 3 \\
\hline & 5. Mengajukan pertanyaan & 4 & 4 & 4 \\
\hline & 6. Menyampaikan pendapat/argumentasi & 3 & 3 & 3 \\
\hline & Jumlah & 40 & 45 & 42,5 \\
\hline & Rata-rata & 3,10 & 3,46 & 3,27 \\
\hline & Persentase & 76,92 & 86,54 & 81,73 \\
\hline
\end{tabular}

Keterangan:

Kriteria Nilai: (1) Tidak baik, (2) Kurang baik, (3) Cukup baik, (4) Baik

2. Pelaksanaan (acting): Pelaksanaan kegiatan adalah hari Rabu, tanggal 1 Februari 2017. Pada tahap ini merupakan pelaksanaan dari rencana yang telah dipersiapkan, yaitu perbaikan berdasarkan siklus 1 dengan langkah-langkah secara ringkas sebagai berikut:

a. Guru memaparkan materi singkat sebagai landasan berpikir awal;

b. Membagi peserta didik dalam kelompok belajar dengan komposisi kemampuan akademis yang bersifat heterogen, artinya setiap kelompok belajar ada peserta didik yang tingkat kemampuan akademiknya lebih tinggi sebagai teman diskusi yang bisa membimbing rekanrekannya untuk belajar; 
c. Membagikan Lembar Kerja Peserta didik sebagai bahan diskusi dalam penunjang proses pembelajaran;

d. Memberikan kesempatan tiap anggota kelompok untuk tampil menyampaikan tanggapan dan penjelasan berkaitan dengan media gambar yang ditampilkan;

e. Peserta didik yang berbeda kelompok dipersilahkan menanggapi dan menyampaikan argumentasi;

f. Peserta didik dibimbing guru secara bersama-sama menyimpulkan materi pembahasan yang telah dilaksanakan dalam proses pembelajaran;

g. Menyampaikan evaluasi kegiatan dan tanya jawab berkaitan dengan proses pembelajaran yang telah dilaksanakan; dan

h. Guru memberikan post test.

3. Pengamatan (observation): peneliti sebagai guru mata pelajaran dibantu kolabolator mengamati jalannya proses pembelajaran sosiologi sesuai yang direncanakan.

4. Hasil Kegiatan dan Pengamatan (lihat Tabel 3).

5. Refleksi (reflecting):

Berdasarkan gambaran hasil pengamatan dan hasil belajar peserta didik pada siklus 2 dapat diperoleh kesimpulan bahwa ada peningkatan yang sangat signifikan beberapa indikator dibandingkan dengan hasil siklus 1 . Sesuai dengan rencana perbaikan hasil siklus 1 , maka gambaran terhadap aktivitas dan partisipasi belajar peserta didik mengalami peningkatan yang cukup tinggi. Hasil pengamatan menunjukkan bahwa rata-rata nilai hasil pengamatan meningkat dari 2,31 (57,69\%) menjadi rata-rata 3,27 (81,73\%). Fenomena yang menarik adalah tingkat antusiasme peserta didik untuk tampil ke depan dan menyampaikan pendapat sangat tinggi lebih dari setengah jumlah peserta didik seluruhnya yaitu 16 orang dari total 31 peserta didik yang hadir. Kenyataan tersebut tentu saja sangat memuaskan dan sesuai harapan bahwa proses pembelajaran berlangsung menarik, partisipasi tinggi dan efektif.

Tabel 4. Rekapitulasi Hasil Tes Peserta Didik Pada Siklus 2

\begin{tabular}{llc}
\hline No. & Uraian & Hasil Siklus 2 \\
\hline 1. & Nilai rata-rata perolehan siswa & 78,29 \\
2. & Jumlah peserta didik yang tuntas belajar & 24 \\
3. & Persentase ketuntasan belajar & $77,42 \%$ \\
\hline
\end{tabular}

Kemudian hasil rata-rata nilai peserta didik juga meningkat dari siklus 1 yaitu dari 70,45 menjadi 78,29. Angka rata-rata yang disebutkan terakhir tersebut berarti sudah melewati nilai KKM yaitu 76. Kemudian jumlah yang tuntas pun juga meningkat cukup tinggi, dari berjumlah 17 orang atau hanya $54,84 \%$ menjadi 24 orang atau 77, 42\%. Persentase tersebut berarti melewati target minimal $75 \%$ yang diharapkan di awal penelitian ini dilaksanakan. Kenyataan tersebut tentu saja sangat menggembirakan karena ada peningkatan yang signifikan daripada hasil proses pembelajaran dan hasil belajar peserta didik pada siklus 1 .

\section{Pembahasan}

Berdasarkan hasil pelaksanaan tindakan mulai pemantauan keadaan awal hingga pelaksanaan tindakan pada siklus 2 maka dapat digambarkan seperti terlihat di Tabel 5. Tabel tersebut menggambarkan bagaimana peningkatan angka rata-rata maupun persentase dari mulai pengamatan awal sampai tahapan siklus 2. Kenyataan tersebut menjelaskan bagaimana efektivitas penerapan rencana proses pembelajaran yang telah disusun serta berbagai perbaikan per tahapan sehingga hasilnya maksimal. Gambaran tabel di atas mencerminkan bahwa variasi media 
pembelajaran yang dalam hal penelitian ini menggunakan media gambar pada materi kelompok sosial untuk mata pelajaran sosiologi sangat efektif dan dapat diterapkan serta dikembangkan untuk materi pelajaran lain yang relevan.

Tabel 5. Pencapaian Hasil Pengamatan dan Hasil Tes Per Tahapan Tindakan

\begin{tabular}{|c|c|c|c|c|}
\hline \multirow{2}{*}{ No } & \multirow{2}{*}{ Indikator } & \multicolumn{3}{|c|}{ Pencapaian } \\
\hline & & Awal & Siklus 1 & Siklus 2 \\
\hline 1 & Partisipasi belajar & $40,00 \%$ & $57,69 \%$ & $81,73 \%$ \\
\hline 2 & Jumlah yang tuntas & 8 & 17 & 24 \\
\hline 3 & Persentase yang tuntas & $25,81 \%$ & $54,84 \%$ & $77,42 \%$ \\
\hline 3 & Rata-rata Nilai Hasil Belajar & 67,23 & 70,45 & 78,29 \\
\hline
\end{tabular}

Penerapan model pembelajaran Examples non examples mendorong rasa ingin tahu peserta didik dan berusaha mencari informasi dengan menginterprestasikan atau memaknai gambar. Guru hanya menyampaikan materi pengantar saja, peserta didik dalam kelompok saling memberikan masukan berkaitan dengan gambar-gambar yang ditampilkan. Partisipasi peserta didik yang tampil cukup menggembirakan dan antusias untuk menyampaikan tanggapan atau argumentasi.

Namun selain beberapa keunggulan dan kelebihannya, model ini juga memiliki beberapa kelemahan dan salah satunya yang paling menonjol dalam kegiatan tersebut adalah prosesnya cukup menghabiskan banyak waktu, sedangkan alokasi waktu yang tersedia cukup terbatas. Pada konteks kelas yang menjadi subjek penelitian secara kebetulan tiga jam sekaligus, maka memungkinkan cukup leluasa waktu. Akan tetapi, jika kelas tersebut hanya memiliki alokasi waktu dua jam atau malah satu jam, maka harus betul-betul mengelola waktu lebih efektif lagi.

Jika saja waktunya lebih lama dan gambar-gambar yang ditampilkan lebih menarik serta relevan dengan tema materi, tentu dapat memberikan kesempatan lebih banyak peserta didik yang ingin tampil untuk memberikan tanggapan, sehingga harapan partisipasi yang lebih tinggi dari peserta didik dapat tercapai maksimal. Oleh karena itu, kemampuan guru dalam mengelola waktu juga perlu menjadi perhatian tersendiri untuk penerapan model pembelajaran Examples non examples.

\section{SIMPULAN}

Berdasarkan hasil penelitian yang telah dipaparkan melalui tahapan dua siklus, maka ada beberapa hal yang menjadi kesimpulan pada penelitian ini yaitu:

1. Penerapan model pembelajaran Examples non examples dapat meningkatkan partisipasi belajar peserta didik Kelas XI.IPS4 SMAN 2 Banjar dalam mata pelajaran sosiologi materi kelompok sosial. Hal tersebut dapat dibuktikan dengan nilai rata-rata hasil pengamatan dari pengamatan awal sampai siklus 2 mengalami peningkatan yaitu 2,31 atau 57,69\% (siklus 1) menjadi 3,27 atau $81,73 \%$ (siklus 2)

2. Penerapan model pembelajaran Examples non examples dapat meningkatkan hasil belajar peserta didik Kelas XI.IPS4 SMAN 2 Banjar dalam mata pelajaran sosiologi materi kelompok sosial. Hal tersebut dapat dibuktikan dengan persentase ketuntasan belajar dan nilai rata-rata tes evaluasi ada peningkatan dari siklus 1 yaitu dengan rata-rata nilai 70,45 mengalami peningkatan pada siklus 2 yaitu dengan rata-rata nilai 78,29 . Sedangkan jumlah peserta didik yang tuntas pun meningkat dari 17 orang atau 54, 84 \% pada siklus 1 menjadi 24 orang atau 77,42\% pada siklus 2.

3. Penerapan model pembelajaran Examples non examples pada peserta didik Kelas XI.IPS4 SMAN 2 Banjar dalam mata pelajaran sosiologi materi kelompok sosial dapat menciptakan suasana 
pembelajaran yang menarik, peserta didik berpartisipasi maksimal dalam proses pembelajaran dan berani menyampaikan tanggapan, pendapat dan argumentasi.

\section{DAFTAR PUSTAKA}

Aqib, Zaenal. (2014). Model-Model, Media, dan Strategi Pembelajaran Kontekstual (Inovatif). Bandung: Yrama Widya.

Arikunto, Suharsimi, Suhardjono, dan Supardi. (2014). Penelitian Tindakan Kelas. Jakarta: PT Bumi Aksara.

Hamalik, Oemar. (2005). Kurikulum dan Pembelajaran. Jakarta: Bumi Aksara.

Hamalik, Oemar. (2003). Proses Belajar Mengajar. Jakarta: Bumi Aksara.

Komalasari, Kokom. (2011). Pembelajaran Kontekstual, Konsep dan Aplikasi. Bandung: PT Refika Aditama.

Kunandar. (2013). Penilaian Autentik (Penilaian Hasil Belajar Peserta Didik Berdasarkan Kurikulum 2013), Suatu Pendekatan Praktis. Jakarta: PT. RajaGrafindo Persada.

Kunandar. (2012). Langkah Mudah Penelitian Tindakan Kelas Sebagai Pengembangan Profesi Guru. Jakarta: PT RajaGrafindo Persada.

Kustandi, Cecep dan Sutjipto, Bambang. (2013). Media Pembelajaran Manual dan Digital. Bogor: Penerbit Ghalia Indonesia.

Nurochim, H.. (2013). Perencanaan Pembelajaran Ilmu-Ilmu Sosial. Jakarta: PT. RajaGrafindo Persada.

Sani, Ridwan Abdullah. (2015). Inovasi Pembelajaran. Jakarta: PT. Bumi aksara.

Shoimin, Aris. (2014). 68 Model Pembelajaran Inovatif Dalam Kurikulum 2013. Yogyakarta: Ar-Ruzz Media.

Sudjana, Nana. (2008). Penilaian Hasil Proses Belajar Mengajar. Bandung: PT Remaja Rosdakarya.

Susilana, Rudi dan Riyana, Cepi. (2009). Media Pembelajaran, Hakikat, Pengembangan, Pemanfaatan dan Penilaian. Bandung: CV Wacana Prima. 